\title{
The Rise of Political Hatred in Twitter Conversations of Indonesian Netizens
}

\author{
http://dx.doi.org/10.25008/jkiski.v6i1.518
}

\section{Iswandi Syahputra}

\author{
Faculty of Social Science and Humanity, Universitas Islam Negeri Sunan Kalijaga \\ J1. Adi Sucipto, Yogyakarta 55281 - Indonesia \\ *Corresponding author: 197304232005011006@uin-suka.ac.id
}

Submitted: February 12, 2021, Revised: March 19, 2021, Accepted: April 19, 2021

Accredited by Kemristekdikti No. 28/E/KPT/2019

\begin{abstract}
This article discusses expressions of hatred as a political category that has become a topic of discourse among Indonesian netizens on Twitter. The Twitter conversations data used in this analysis were obtained through a Twitter thread reader application operated by DEA (Drone Emprit Academic). As a political category, hatred is considered new. It emerged as and became a conversational topic for netizens on Twitter due to various political promises President Joko Widodo has made during his campaign and has not fulfilled. Political hatred has spread extensively owing to Twitter leading to absolute freedom of expression. On Twitter, political hatred has increased because of two main clusters during the 2019 Presidential Election campaign. The two clusters represent two pairs of presidential and vice-presidential candidates, namely Joko Widodo-Ma'ruf Amin (Number 01/JKW-MA) and Prabowo Subianto-Sandiaga Uno (Number 02/PS-SU). This study may have implications on broader hatred-based political conflict. Additionally, political hatred may also have implications on the waning of the public's function to criticize political actors and the government because criticism may be suppressed on the basis of it being an expression of hatred. This will, accordingly, turn into a new dilemma in a democratic country, between freedom of expression and potential rise of new authoritarianism.
\end{abstract}

Keywords: General election; netizens; new media; polarization; political hatred

\section{Introduction}

Social media such as Twitter has become a means for exchanging information among citizens (Lim, 2017) due to the interactive communication era transpiring before us today (Khang, $\mathrm{Ki}, \& \mathrm{Ye}$, 2012). As a result, every citizen active on the internet, commonly known as netizens, have played a role as an actor of political change (Gordon, 2017). The term netizen is the combination of two words, namely network and citizen, and it was coined by Michael Hauben in 1995. Netizen is defined as citizens who are active on and mutually interact in a system of internet network (Hauben \& Hauben, 1997). The interactions conducted by netizens have become new political activities. According to Levinson
(2014), new social interactions within the cyberculture are considered as new new media, i.e. all information in all forms being disseminated more rapidly and expansively, thus resulting in the formation of new concepts, new lifestyles, and even new power.

One of the negative impacts this new form of interaction has within the context of Indonesian politics is the propagation of hate speech instigated by differences in political choice, particularly during the 2014 Indonesian Presidential Election. Expressing hatred on account of differences in political choice has resurfaced on a much more expansive scale in the 2019 Presidential Election. Political hatred is undoubtedly associated with the general understanding of hate speech or expression 
of hatred. According to George (2017), hate speech may be defined as "any expression that vilifies an identifiable group and thus prompts harm to its members". Whereas Lenkova (1998) provides a definition of hate speech as "the use of very precise discriminatory and selective vocabulary which tries to legitimize negative thinking about all those who are not 'us', those who are 'others". Meanwhile, Simpson (2013) presents a principle of hate speech, which is identity based contempt, regardless of how one uses it or how it may affect the target.

Hate speeches that are expressed online have drawn quite the attention of several researchers and academicians in the last few years, such as studies done by Pohjonen (2019), Alkiviadou (2019), BenDavid \& Matamoros-Fernández (2016). Even before the advent of social media, like Twitter, various expressions of hatred had emerged on a number of online channels. Hence, Spiegel (1999) had even predicted that the internet will become another means of communication for racists and "haters" to spread their messages. In the same line, Nemes (2002) considers the internet as extremely vital to those wanting to spread messages of hate. Duffy (2003) even states that the internet or the web is a contributor in the culture of hate and violence. Commaerts (2009), in his study, shows that the internet functions as a space where racial hatred and discriminatory conversations are held. These activities take place in blogs and various online chat forums. Haters interact with one another and are mutually connected.

Nevertheless, these studies have yet to specifically discuss political hatred in the context of political discourses or activities occurring on today's social media, particularly among netizens in Indonesia. While in fact, a survey conducted by the Association of Indonesian Internet Service Provider (APJII, 2019) states that the number of internet users in Indonesia in 2018 was $64.8 \%$ or 171.17 million users out of the 264.16 million Indonesian population. The number continues to climb year by year.

One of the political activities that netizens on Twitter engage in is the spreading of hate due to differences in political choice in the run-up to the 2019 Presidential Election. The political activities taking place on Twitter may be considered as political hatred. In this study, political hatred is, subsequently, defined as communication activities on Twitter in the form of texts, pictures, or videos containing revilement, insult, ridicule or that are demeaning perpetrated by an individual or group against another individual or group on account of differences in political choice with the intent of suppressing their voices, cornering and pressuring them, or inciting anger, embarrassment, guilt, and various other uncomfortable feelings or conditions to others in order to maintain, oust, and claim political power in all its forms.

The 2019 Indonesian Presidential Election only presented two pairs of presidential and vicepresidential candidates running for the 2019-20124 term. The first pair of candidates, which was given the number 1, are Joko Widodo and Ma'ruf Amin (JKW-MA). Joko Widodo is the incumbent President of Indonesia for the 2014-2019 term who won the 2014 Indonesian Presidential Election. The second pair of candidates, which was given the number 2, are Prabowo Subianto and Sandiaga Uno (PS-SU). Prabowo Subianto was a presidential candidate in the 2014 Indonesian Presidential Election who lost to Joko Widodo.

The supporters of the two pairs of presidential and vice-presidential candidates were both active in their social media activities, particularly on Twitter. Both supporters mutually expressed their hatred on Twitter. As a result, their political activities on Twitter had led to the polarization of netizens into two large groups (clusters) (Syahputra, 2017). Given the background, this article aims to address the question of how political hatred on Twitter emerged in the conversations held by Indonesian netizens?

\section{Theoretical Framework}

Political hatred in Indonesia is inseparable from the global phenomenon sweeping the world today. The Brexit phenomenon (Hänska-Ahy \& Bauchowitz, 2017; Gorodnichenko, Pham \& Talavera, 2018), which followed Donald Trump's election victory as the US President in the 2016 election (Ott, 2017; Enli, 2017; Schill \& Hendricks, 2018; Baumgartner \& Towner, 2018), and the political dynamics taking place in the Middle East which is subsequently known as the Arab Spring (Altable, 2016; Bruns, Highfield \& Burgess, 2013, Bebawi, Bossio, Burns \& Highfield, 2014) are three phenomena that have set the global context for the rise of political hatred in Indonesia. Brexit and Donald Trump's victory have brought hate into social media. Weisberg (2016) considers the phenomena as a 'wave', while Desmond (2016) uses the term 'barrage', and Sidahmed (2016) opted for using the term 'deluge' of noxious hate. As for the Arab Spring, which took place in the Middle East, it is undeniable that the phenomenon emerged out of social media activities. The three phenomena above may be identified as triggers in the formation of highly aggressive political activity in the culture of new media (cyber media) in Indonesia today. 
Among the three global phenomena (Brexit, Trump, and Arab Spring), Donald Trump winning the election and becoming the President of the U.S. is most similar to the political context that Indonesia is currently experiencing. In the United States, Donald Trump's victory drew significant attention from mass media and became the talk of netizens on social media such as Twitter. Trump's victory has encouraged the rise of white nationalist and supremacist in America, commonly known as the alt-right, or alternative right. This is a political group that emerged from the ruling group to confront opposition or competition from the nonruling political group that is known as the left right.

Various mass media highlighted the phenomenon as The Alt-Right and a Deluge of Hate, which turned into a rather tough debate on Twitter. Okeowo (2016) in the New Yorker reviewed the phenomenon through the article Hate Is on the Rise After Trump's Election, while Sidahmed (2016) in the Guardian reported the phenomenon as Trump's Election led to Barrage of Hate, and Desmond (2016) in Vox released an article titled The Wave of Post-Election Hate Reportedly Sweeping the Nation, Explained. King (2016) specifically wrote an article in Vocativ under the title The Year in Hate: From Donald Trump to the Rise of the Alt-Right.

Numerous reports pertaining to hate and its conversations on social media had conveyed the word 'hate' verbally directed at Trump through expressions like "I hate Trump". Although this expression of hate is directed at a political official, such kind of hatred is an emotional phenomenon or expression, it has yet to become a political phenomenon or expression. As an emotional expression, the hate that people articulate is a personal matter. Feelings of hate are driven by personal differences and dislike toward another person's attitude, behavior, or style. However, as a political phenomenon or expression, feelings of hate are driven by dislike toward another individual's personal function as a public or political official whose performance does not meet the hater's expectations. In practice, both categories of hatred overlap one another because hate, characteristically, influences or stimulates other matters more rapidly.

\section{Material and Methodology}

Data used in this study are conversations or statuses of netizens on Twitter containing political hatred. The data were gathered during the campaign period of the Presidential Election from December 2018 to January 2019 by employing a unique method provided by DEA (Drone Emprit Academic). DEA is a big data system with the ability to capture and analyze the conversations of netizens on social media, particularly Twitter in real time. DEA facilitated data collection and the research design. The method used in this research is distinct as it considers online communication not only as "contents", but also as a virtual social interaction that is a new cultural artifact. Hence, the method paid close attention to netizens' conversations on Twitter during the debate of the presidential and vice-presidential candidates.

Specifically, the present study focuses on Jokowi (JKW) and Ma'ruf Amin (MA) as the number 01 presidential and vice-presidential candidate pair and Prabowo Subianto (PS) and Sandiaga Uno (SU) as the number 02 presidential and vice-presidential candidate pair to be used for mapping out the SNA (Social Network Analysis). The SNA mapping resulted in clusters of Twitter conversations carried out by netizens. These clusters serve as data samples of netizens' conversations that were subsequently focused on contents relating to expressions of hatred. For that purpose, a search engine was used to find hashtags from the data base that contained expressions of hatred. The hashtags were naturally selected as they emerged among the netizens in every cluster of conversations they had on Twitter, they were not arranged based on criteria that we (the researchers) made. This was done with the purpose of analyzing the existence of expressions of hatred as a political activity that netizens engage in throughout the period of debates among the presidential and vicepresidential candidates. As such, the current study is essentially a research that explores political hatred on Twitter, which may potentially be investigated more deeply and comprehensively in the future.

Once data were collected, the clusters of conversations were analyzed. The analysis focused on hashtags containing expressions of hatred and on particular accounts that were identified as influencers. In the SNA, some account names emerged and they are enlarged to indicate that they are influencer accounts having substantial influence in the conversations by retweeting (see Figure 3 ). The data were subsequently processed into several categories leading to a generalization that is accordingly presented in an interpretative and descriptive manner. The final part of the data analysis was to seek and find interrelations and coherence in the SNA map with various theories or prior literary sources. This was done in order to find the main theme of the research as an answer to the research question we posed. 


\section{Result and Discussion}

Political hatred in the conversations held by netizens on Twitter emerged during the debates of the presidential and vice-presidential candidate pairs, between Joko Widodo-Ma'ruf Amin (JKWMA) and Prabowo Subianto-Sandiaga Uno (PSSU). Activities concerning netizens' conversations on Twitter are assembled into two large clusters (Figure 1).

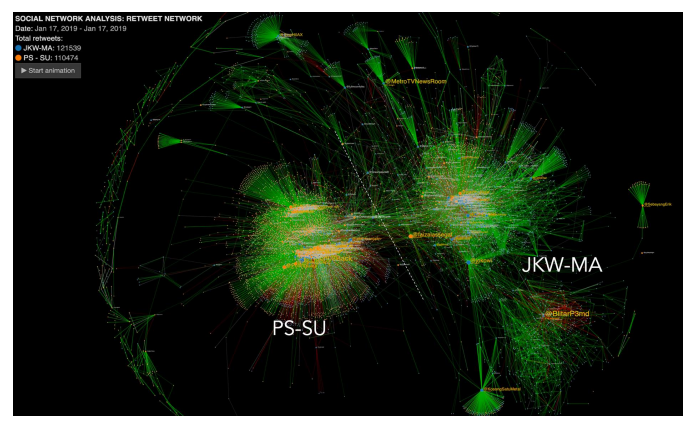

Figure 1. A Social Network Analysis (SNA) map of conversations relating to the First Round of Debate between the Indonesian Presidential Candidates held on the $17^{\text {th }}$ of January 2019. Source: DroneEmprit Acadamic, 2019

These clusters were formed based on the patterns of conversations that every Twitter account had during the First Round of Debate between the Indonesian Presidential Candidates on January $17^{\text {th }} 2019$, i.e. number 01 pair of Joko Widodo-Ma'ruf Amin (JKW-MA) against number 02 pair of Prabowo Subianto-Sandiaga Uno (PS$\mathrm{SU})$. According to the SNA map, netizens on Twitter who supported JKW-MA were spread out in several clusters (groups), while those in support of PS-SU remained solid within a single cluster (group). Clusters of JKW-MA supporters shared their tasks, there were those who endorsed the JKW-MA pair, and there are those who attacked the PS-SU pair. Meanwhile, netizens supporting the PS-SU pair were merely consolidated within one cluster and they both endorsed PS-SU and attacked JKW-MA in chorus. In the conversations, it was found that netizens frequently conveyed expressions of hatred in various forms such as sentences, images, memes, videos, or hashtags like \#RakyatSudahMuak (\#ThePeopleAreFedUp).

Such hashtags were able to function as a means to coordinate, consolidate, and distribute even more Twitter users, despite their being mutually unconnected. The more that a hashtag became a conversation topic among netizens, the greater the influence it has upon them. The polarization of these two groups of netizens spreading political hatred on Twitter would often lead to hashtag wars to show which group maintained the greater influence on Twitter ( Figure 2).

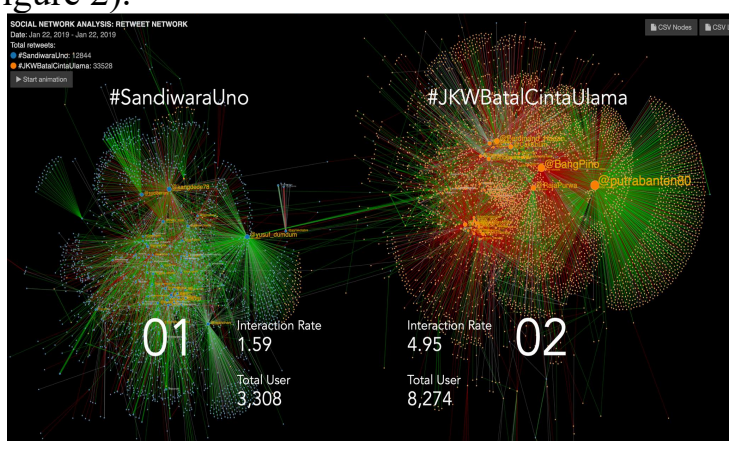

Figure 2. A Social Network Analysis (SNA) map relating to the conversations of netizens on the hashtag war between the number 01 presidential candidate pair (Jokowi-Ma'ruf Amin) and the number 02 presidential candidate pair (PrabowoSandiaga) on the $22^{\text {nd }}$ of January 2019.

Source: DroneEmprit Acadamic, 2019

These netizen groups were established as a result of the differing political support and choice they made during the 2019 Indonesian Presidential Election. According to the SNA map, netizens in support of Jokowi-Ma'ruf Amin (Number 01) launched the hashtag \#SandiwaraUno (\#UnoTheatrics) as a retaliation against netizens in support of Prabowo-Sandiaga Uno (Number 02) who initiated the hashtag \#JKWBatalCintaUlama (\#JKWCancelledLovingUlema).

The hashtag war concerning the later occurred within the context of Jokowi planning to release Abu Bakar Ba'asyir, an ulema imprisoned on charges of terrorism. However, Jokowi did not go through with the decision and the release was cancelled. This had consequently led to netizens creating the hashtag \#JKWBatalCintaUlama (\#JokowiCancelledLovingUlema). In order to intercept the dominance of netizen conversations on Twitter regarding this particular hashtag, supporters of Jokowi-Ma'ruf Amin launched the hashtag \#SandiwaraUno (\#UnoTheatrics). This hashtag is a wordplay on the name Sandiaga turning it into sandiwara (theatrics) as JokowiMa'ruf Amin supporters considered Sandiaga using political theatrics/drama excessively to gain voters' sympathy.

The hashtag \#JKWBatalCintaUlama indicates content relating to religious identity expressed by netizens supporting the PS-SU pair. Religious identity was used since Jokowi's vice-presidential candidate Ma'ruf Amin (MA) is an ulema positioned as the General Chair of the Indonesian Ulema Council (MUI). Netizens' conversations on Twitter regarding religious identity had 
subsequently led to JKW-MA's stronghold to request the General Election Commission (KPU) to conduct a test for the presidential candidates to read the Quran (Muslim's holy book) as a requirement to be the Indonesian President. Such discourse emerged because Prabowo Subianto (presidential candidate number 02) has been known as being unable to read the Quran (Figure 3). JKW-MA's stronghold seems to have dominated the conversations on Twitter in raising the issue of Quran reading test in the nomination process of the President of Indonesia.

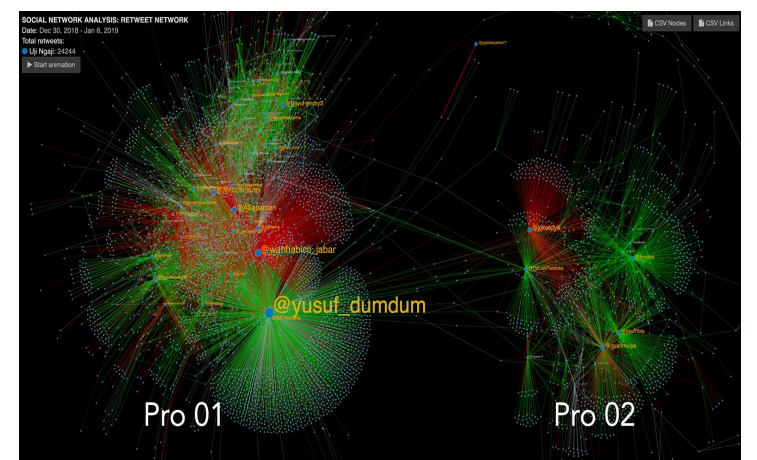

Figure 3. A Social Network Analysis (SNA) map relating to the conversations of netizens on religious identity used in conveying expressions of hatred on the $6^{\text {nd }}$ of January 2019.

Source: Drone Emprit Acadamic, 2019

This indicates that political hatred among Twitter users is recognizable based on their alliance or the political support they provide to the two pairs of presidential and vice-presidential candidates. This implies that the conversations of netizens on Twitter that contain political hatred emerged and become polarized into two major groups due to differences in political support or preference. This explains that through Twitter, hatred can emerge as a result of political support and differences. The polarization of political groups that mutually despise each other has revolutionized content production and communications in the new media culture. The presence of Twitter is increasingly exploited to express hatred by netizens (Badjatiya et al., 2017; Burnap \& Williams, 2015). Twitter has become a channel that is no longer neutral as it has developed into a means for disseminating hatred leading to hate crime.

\section{Expressions of Hatred as New Media Culture}

Hate can be conveyed through or contained within a discourse, conversation, and speech via certain metonymy. Metonymy is a figure of speech wherein words, dictions, or sentences are selected and used to state something indirectly but still closely associated with the intended meaning. In practice, metonymy refers to the use of one sentence or word that is not a hate word but can be associated with something (someone) the speaker implies and dislikes. Therefore, the delineation of political hatred, through the perspective of metonymy, can be expanded. Even though feelings of hate are not expressed directly and verbally, the use of the stealthy metonymy technique may turn seemingly non-hateful expressions into hate speech.

As a political category, hate speeches, which are expressed verbally and directly or through metonymies, are expressions containing revilement, insult, ridicule or that are demeaning perpetrated by an individual or group against another individual or group on account of differences in political choice with the intent of suppressing their voices, cornering and pressuring them, or inciting anger, embarrassment, guilt, and various other uncomfortable feelings or conditions to others in order to maintain, oust, and claim political power in all its forms. In Indonesia, political hatred emerged as a result of the political struggle taking place within the new media culture. Lim (2017) describes the phenomenon in Indonesia as the freedom to hate. The influence of social media, particularly Twitter, in Indonesia today serves as an example of how political actors and citizens and fellow netizens utilize social media in the political process (Johansson, 2016).

In the new media culture, various relational patterns between citizens and political actors have undergone changes and found new means of communication between political parties and their constituencies (Lim, 2017). In terms of politics and social media, Twitter can be used by politicians to boost potential votes (Caplan, 2013). Specifically, Beers (2014) explains that activities on social media, particularly those relating to politics during election time are the most appealing to citizens active on social media. However, according to Lim (2014), these social media activities do not guarantee political change. This is because social media is not an agent of social change. Public participation and activities on social media is a crucial element for political change to happen in Indonesia. This means that social media and citizens' activities on social media may play a part in political change (Gordon, 2017). While in fact, it is not impossible for laypersons or other educated individuals who are active on social media to disseminate negative information (Godes \& Mayzlin, 2004). The negative information conveyed via social media can subsequently trigger anger, anxiety, and sorrow (Barrett \& James 1998).

Negative information on politics that has been disseminated would not only flourish on open 
social media platforms such as Twitter or Facebook, as it would also spread via WhatsApp or other closed or restricted virtual group platforms. Conversation pockets or political discourse activities conducted by citizens through these various social media channels will consequently lead to what Grömping (2014) considers as an echo chamber. An echo chamber may be defined as conversations occurring on several social media platforms that develop into something deliberative and sealed off from the perspectives of other differing groups (enclave group).

In those conversation enclaves, anger, anxiety, sorrow, and hate develop much more progressively since communications on social media may happen between people who are not acquainted with one another at all. These various emotional conditions emerging among social media activities may heighten the spread of hate speech (Ahmed, 2010). In the case of Indonesia, varying expressions of hatred have emerged from conversations relating to religion and politics (George, 2017).

\section{The Emergence of Political Hatred}

Expressions of hatred that bear religious and political contents on Twitter in Indonesia emerged along with the advent of social media. This is subsequently followed by the widespread use of Twitter among Indonesians. According to research conducted by Nugroho and Syarief (2012), social media like Facebook and Twitter have established new relations between the middle and upper classes. The relationships that are mediated via social media serve as a political basis in the freedom of expression for the society. Due to its strength in binding relations and capacity for mass mobilization, Twitter is often utilized to conduct various mass rallies for protesting or expressing opinions.

During the period of Twitter's emergence in Indonesia, its use was limited to the educated urban communities. At this initial stage, Twitter was also used to fortify solidarity in rejecting hate speech often expressed by the Islamic Defenders Front (Front Pembela Islam - FPI), because FPI is considered to have frequently conveyed various expressions of hatred in their activities. According to Woodward (2015) and Djelantik (2016), during the 2014 Presidential Election, politically speaking, FPI was affiliated to Prabowo Subianto who was the presidential candidate at the time. This is because Prabowo is considered more open to the agenda of the Islamist group, whereas Jokowi accepted the agenda of the inclusive Islamic group (Njoto-Fiellard, 2015).
FPI's activities before the 2014 Presidential Election, which often conveyed various religionbased expressions of hatred, were considered most disconcerting by netizens, and this resulted in a solidarity movement on Twitter to reject FPI by using the hashtag \#IndonesiaTanpaFPI (\#IndonesiaWithoutFPI). The conversations netizens held on social media with the hashtag \#IndonesiaTanpaFPI had subsequently succeeded in pushing for a protest rally rejecting FPI (Nugroho \& Syarief, 2012). At the time, the virtual conversations on Twitter positioned FPI as a threat to religious pluralism in Indonesia.

Then, in 2012, Joko Widodo and running mate Basuki Tjahaja Purnama (commonly known as Ahok) were elected as Governor and ViceGovernor of Jakarta SCR in the Jakarta SCR Regional Election. Jokowi and Ahok's election victory is inseparable from the support and network of volunteers, particularly on social media such as Twitter. The emergence of political volunteers is considered by Norquay (2008) as an organization without organization (unstructured organization) which was brought about as a result of the revival of identity politics. During the Jakarta SCR Regional Election campaign period in 2012, Jokowi-Ahok's volunteers in social media were mobilized through JASMEV (Jokowi Ahok Social Media Volunteers), which was formed on the $12^{\text {th }}$ of August 2012. The formation of JASMEV is inseparable from the global trends in politics which at the time considered social media as a powerful element in political campaigns. Barrack Obama's victory in becoming the US President in 2008 can be a reference for a political victory achieved by utilizing the power of social media. Social media was properly organized at the time in order to mobilize social movements that were supportive of their goals (Shirky, 2011).

JASMEV can be considered as the first model of political campaign on social media organizing political volunteers. On social media such as Twitter, fellow volunteers are interconnected. Such interconnectivity forms a broad, massive, and continuous information network in real time. Volunteers and social media users optimally were the vital element in bringing the Jokowi-Ahok pair to victory in the 2012 Jakarta SCR Regional Election. The activities of the volunteers on social media were extremely helpful in spreading around mentions or buzzers for Jokowi. Their number even reached two million. This number was the result of more than 900 thousand different accounts (unique users) (Indrietta, 2012). The volunteers had shaped and led the netizens' opinions by using a technique that Lim (2003) considers to have the following attributes: light package, headline 
appetite, trailer vision.

The presence of these volunteers and their activities on social media in the 2012 Jakarta SCR Regional Election continued to the 2014 Presidential Election. There were two pairs of candidates running for president in 2014, Joko Widodo with Jusuf Kalla as his running mate and Prabowo Subianto with Hatta Rajasa as his. As we all know, the 2014 Presidential Election was won by the Joko Widodo and Jusuf Kalla pair and they were subsequently inaugurated as the President and Vice-President of the Republic of Indonesia for the 2014-2019 period. Jokowi's victory in the Presidential Election is inseparable from the support of the volunteers and their activities on social media. Nugroho and Setia (2014) note that there were 148 networks of Jokowi volunteers, including JASMEV (Jokowi Advanced Social Media Volunteers). Thus, Mietzner (2014) states that the mobilization and optimization of supporter/volunteer networks (grassroots volunteerism) on social media indicated not only the characteristic of the 2014 Presidential Election, but also the victory of Jokowi's supporters.

The activities of Jokowi's voluntary supporters in the 2014 Presidential Election on social media, particularly Twitter, provided a positive image on Jokowi's figure as a presidential candidate rising from the common people. Jokowi's victory in the 2014 Presidential Election is regarded by Mietzner (2014) as the victory of grassroots volunteerism against machine politics. According to Woodward (2015), Jokowi's image in the 2014 Presidential Election was portrayed as a moderate Muslim, a populist, a tolerant pluralist and defender of justice with great concern in the education sector. Jokowi was also portrayed as a hard worker and populist, but lacking good political communication ability (Djelantik, 2016). Nevertheless, according to his political rivals, Jokowi was instead portrayed as an enemy of Islam, a supporter of Christians, anti-Muslim, Zionist, and puppet president (Njoto-Feillard, 2015).

Jokowi's election as the President of Indonesia through the 2014 Presidential Election had marked the emergence of political hatred and religion-based hatred. As a political category, hatred emerged due to the fact that Jokowi as the president-elect was considered to have broken his political promise as the Governor of Jakarta SCR. During his campaigns ahead of the Governor of Jakarta SCR Election in 2012, Jokowi promised to hold the post of Jakarta's governor for five years until the end of his term in 2017. However, just two years into his gubernatorial term, Jokowi began running for president. Jokowi's broken promise had become the start of hatred as a political category because he himself had broken his political promise to hold the post of governor of Jakarta SCR for five years from 2012 until 2017. Jokowi's political promise was conveyed during his campaigns in the 2012 Jakarta SCR Regional Election (Kuwado, 2014).

Among the netizens in Indonesia, political hatred of Jokowi continued after he won the 2014 Presidential Election. When Jokowi was elected as the President of the Republic of Indonesia, he promised to show a new political style that is in line with the spirit of reform. However, according to Muhtadi (2015), one year into his presidency, Jokowi had failed to fulfill his promise to reform, in most part due to a combination of external and personal factors. He failed to show leadership in issues of anti-corruption and human rights.

Heading into the second and subsequent years of Jokowi's term, the conversations on Twitter containing political hatred began to surface when Jokowi's administration adopted policies that went against the political promises he made during the campaign. For instance, his promise of not importing rice made during the campaign was broken (Maharani, 2014), after becoming president, Jokowi not only imported rice, but also imported salt and corn (Yasmin, 2018). Meanwhile, in terms of democracy, Power (2018) assesses that there is a decline in the quality of democracy under Jokowi's leadership. Aspinall and Mietzner (2019) also considers that Jokowi's leadership has the potential to erode various democratic institutions.

\section{Conclusions}

As a political category, hatred emerged on account of unfulfilled political promises in which some were even violated by President Jokowi. This hatred is directed towards the President's political policies, not towards Jokowi personally as the President. However, it is rather difficult to distinguish between politically driven hate contents and those directed personally at Jokowi as the President among the numerous conversations netizens that take part in social media such as Twitter. Such difficulty occurs since these expressions of hatred originate from the group that has politically been defeated and is facing resistance from the political group in support of Jokowi as President.

Both political groups actively launch political hatred ridden contents on Twitter resulting in the formation of political polarization between netizens of the opposition group and the netizens of the incumbent group. Since both groups mutually express political hatred ridden contents on Twitter, 
which possess a number of specific and unique characteristics such as hashtags and the use of anonymous (pseudonymous) accounts, consequently, political hatred can easily spread with tremendous speed and extensive reach. This is due to the fact that both groups utilize anonymous (pseudonymous) accounts on Twitter.

Therefore, this study will have implications in obscuring the function of public criticism of political elites and the government. Since the group that often disseminates political hatred is also the one that is often critical of the Jokowi administration, a criticism directed at the government may be construed as an expression of hatred. Within a democratic political system with strong identity politics like Indonesia, criticisms of the government may subsequently be considered as expressions of hatred. This perspective may result in political hatred becoming a new category as a cyber crime or political crime in the cyber world. This will also turn into a new dilemma for democratic countries such as Indonesia, as it is caught between the freedom of expressing one's opinions and the possibility of new authoritarianism emerging within the culture of the cyber community. Additionally, the intensifying polarization of netizens on Twitter as a result of differing political choice may have implications in revitalizing mass media as a neutral and objective source of information for the netizens, in which the mass media may also serve as a link for the two differing groups.

\section{References}

Ahmed, S. (2010). The Promise of Happiness. Durham, NC: Duke University Press.

Alkiviadou, N. (2019). Hate speech on social media networks: towards a regulatory framework? Information \& Communications Technology Law, 28(1), 19-35.

Altable, L. P. (2016). The Arab spring before the Arab spring: A case study of digital activism in Tunisia. Global Media Journal, 4(1-2), 1932.

APJII. (2019). Infografis penetrasi dan prilaku pengguna internet di Indonesia. [Infographic on the penetration and behaviour of internet users in Indonesia] Retrieved from https://www.apjii.or.id/content/read/39/264/S urvei-Internet-APJII-2017 on December 27, 2019.

Aspinall, E \& Mietzner, M. (2019). Indonesia's democratic paradox: competitive elections amidst rising illiberalism. Bulletin of Indonesian Economic Studies, 55(3), 295-317.

Badjatiya, P., Gupta, S., Gupta, M, \& Varma, A. (2017, April). Deep learning for hate speech detection in tweets. Proceedings of $A C M$ $W W W^{\prime} 17$ Companion (pp. 759-760). Perth : WWW'17.

Barrett, L. F., \& James A. R. (1998). Independence and bipolarity in the structure of current affect. Journal of Personality and Social Psychology, 74(4), 967-84.

Baumgartner, J.C \& Towner, T.L. (2018). The internet and the 2016 presidential campaign. Lahnam, Maryland : Lexington Book.

Bebawi, S., Bossio, D., Bruns, A., \& Highfield, T. (2014). The Arab spring on twitter: language communities in \#egypt and \#libya. Palgrave: Macmillan.

Beers, S. (2014). Shallow or rational public spheres? Indonesian political parties in the twitter-sphere. SEARCH: The Journal of the South East Asia Research Centre for Communications and Humanities, 6(2), 1-23.

Ben-David, A., \& Matamoros-Fernández, A. (2016). Hate speech and covert discrimination on social media: monitoring the facebook pages of extreme-right political parties in Spain. International Journal of Communication 10, 1167-1193.

Bruns, A., Highfield, T., \& Burgess, J. (2013). The Arab spring and social media audiences: English and Arabic twitter users and their networks. American Behaviora Scientist, 57(7), 871-898.

Burnap, P. \& Williams, M.L. (2015). Cyber hate speech on twitter: An application of machine classification and statistical modeling for policy and decision making. Policy and Internet, 7(2), 223-242.

Cammaerts, B. (2009). Radical pluralism and free speech in online public spaces: The case of North Belgian extreme right discourses. International Journal of Cultural Studies, 1(6), 555-575.

Desmond, H. J. (2016, December 2). The wave of post-election hate reportedly sweeping the nation, explained. Vox, 17 Retrieved from http://www.vox.com/2016/11/17/13639138/tr ump-hate- crimes-attacks-racismxenophobia-islamophobia-schools.

Djelantik, S. (2016). Political communication and international public opinion: A study of Jokowi's Indonesia. Journal of Media Critiques, 2 (8), 147-160.

DroneEmprit Academic. (2019). Drone Emprit Academic Open Data from Universitas Islam Indonesia website: https://dea.uii.ac.id/

Duffy, M.E. (2003). Web of hate: A fantasy theme analysis of the rhetorical vision of hate groups online. Journal of Communication Inquiry, 27(3), 291-312. 
Enli, G. (2017). Twitter as arena for the authentic outsider: Exploring the social media campaigns of Trump and Clinton in the 2016 US presidential election. European Journal of Communication, 32(1), 50-61.

George, C. (2017). Hate spin: the manufacture of religious offense and its threat to democracy. Cambridge: The MIT Press.

Godes, D., \& Mayzlin, D. (2004). Using online conversations to study word of mouth communication. Marketing Science, 23(4), $545-60$.

Gordon, S. (2017). Online communities as agents of change and social movements. Harshey: Information Science Reference.

Gorodnichenko, Y., Pham, T., \& Talavera, O. (2018). Social media, sentiment and public opinions: Evidence from \#Brexit and \#Uselection. Stanford, : National Bureau of Economic Research.

Grömping, M. (2014). Echo chambers' partisan Facebook groups during the 2014 Thai election. Asia Pacific Media Educator. London: SAGE Publications.

Hänska-Ahy, M. \& Bauchowitz, S. (2017). Tweeting for Brexit: How social media influenced the referendum. In J. Mair., T. Clark, N. Fowler, R. Snoddy, \& R. Tait (Eds.), Brexit, Trump and the media. Bury St. Edmunds : Suffolk Abramis Academic Publishing.

Hauben, M. \& Hauben, R. (1997). Netizens: on the history and impact of usenet and the internet. Los Alamitos : IEEE Computer Society Press. Indrietta, N. (2012, September 18). PoliticaWave: Isu SARA tak laku di putaran kedua. Tempo.co. Retrieved from https://m.tempo.co/amp/430219/politicawave -isu-sara-tak-laku-di-putaran-kedua

Johansson, A. C. (2016).Social media and politics in Indonesia. (Working Paper No. 42). Stockholm: Stockholm School of Economics Asia.

Khang, H., Ki, E., \& Ye, L. (2012). Social media research in advertising, communication, marketing and public relations 1997-2010. Journalism and Mass Communication Quarterly, 89(2), 279-298.

King, J. (2016, December 21) This year in hate: From Donald Trump to the rise of the alt-right. Vocativ. Retrieved from http://www.vocativ.com/383234/hate-crimedonald-trump-alt-right-2016/.

Kuwado, F. J. (2014, March 7). Beredar video janji Jokowi pimpin Jakarta lima tahun. Retrieved from

https://megapolitan.kompas.com/read/2014/0
3/07/0635111/Beredar.Video.Janji.Jokowi.Pi mpin.Jakarta.Lima.Tahun

Lenkova, M. (ed). (1998). Hate speech in the Balkans. Athens : ETEPE.

Levinson, P. 2014. New New Media. Boston : Pearson.

Lim, M. (2003). The internet, social network, and reform in Indonesia. In N. Couldry \& D. Miller (Eds.) Contesting Media Power: Towards a Global Comparative Perspective, Lanham: Rowan and Littlefield.

Lim, M. (2003). The internet, social network, and reform in Indonesia. In N. Couldry \& D. Miller (Eds.) Contesting Media Power: Towards a Global Comparative Perspective, Lanham: Rowan and Littlefield.

Lim, M. (2014). Seeing spatially: People, networks, and movements in digital and urban spaces. International Development and Planning Review, 36(1), 51-72.

Lim, M. (2017). Freedom to hate: social media, algorithmic enclaves, and the rise of tribal nationalism in Indonesia. Critical Asian Studies, 49(3), 411-427.

Maharani, D. (2014, July 2). Jokowi: Petani harus dimuliakan, stop impor!. Retrieved from https://nasional.kompas.com/read/2014/07/02 /2151345/Jokowi.Petani.Harus.Dimuliakan.S top.Impor

Mietzner, M. (2014). Indonesia's 2014 elections how Jokowi won and democracy survived. Journal of Democracy, 25(4), 111-125.

Muhtadi, B. (2015). Jokowi's first year: a weak president caught between reform and oligarchic politics. Bulletin of Indonesian Economic Studies, 51(3), 349-368.

Nemes, I. (2002) Regulating hate speech in cyberspace: Issues of desirability and efficacy. Information \& Communications Technology Law, 11(3), 193-220.

Njoto-Feillard, G. (2015). Hizbut Ttharir Indonesia in 2014: The political economy of discontent. Singapore: ISEAS Publishing.

Norquay, G. (2008). Organizing without an organization: The Obama networking revolution. Policy Options, 29(9), 58-61.

Nugroho, B. \& Setia, M.Y. HLM. (2014). Jokowi people power. Jakarta: Gramedia Pustaka Utama.

Nugroho, Y. \& Syarief, S. S. (2012). Beyond clickactivism? new media and political processes in contemporary Indonesia. Jakarta : Friedrich Ebert Stiftung.

Okeowo, A. (2016, November 17). Hate on the rise after Trump's election. The New Yorker. Retrieved 
http://www.newyorker.com/news/newsdesk/hate-on-the-rise-after-trumps-election.

Ott, B.L. (2017). The age of Twitter: Donald J. Trump and the Politics of Debasement. Critical Studies in Media Communication, 34(1), 2017, 59-68.

Pohjonen. M. (2019). A comparative approach to social media extreme speech: online hate speech as media commentary. International Journal of Communication, 13, 3088-3103.

Power, T.P. (2018). Jokowi's authoritarian turn and Indonesia's democratic decline. Bulletin of Indonesian Economic Studies, 54(3), 307338.

Schill, D.J., \& Hendricks, J.A. (2018). The Presidency and social media discourse, disruption, and digital democracy in the 2016 presidential election. New York : Routledge.

Shirky, C. (2011). The political power of social media. ForeignAffairs,90(1), 28-41.

Sidahmed, M. (2016, November 26). Trump's election led to 'barrage of hate', report finds. The https://www.theguardian.com/society/2016/n ov/29/trump-related- hate-crimes-reportsouthern-poverty-law-center.

Simpson, R.M. (2013). Dignity, harm and hate speech. Law \& Philosophy, 32(6), 701-728.
Spiegel, M.L. (1999). Hate speech, civil rights, and the internet: The jurisdictional and human rights nightmare. Albany Law Journal of Science \& Technology, 9(2), 375-399.

Syahputra, I. (2017). Demokrasi virtual dan perang siber di media sosial: Perspektif netizen Indonesia. [Virtual democracy and cyberwar on social media: an Indonesian netizen's perspective]. Jurnal ASPIKOM, 3(3), 457-475.

Weisberg, J. (2016, November 1). The alt-right and a deluge of hate. Slate No. 1. Retrieved from https://slate.com/news-andpolitics/2016/11/how-the-alt-right-harasseddavid-french-on-twitter-and-at-home.html

Woodward, K.E. (2015). Indonesian schools: Shaping the future of Islam and democracy in a democratic muslim country. Journal of International Education and Leadership, 5 (1), 1-23.

Yasmin, P.A. (2018, December 27). Heboh RI impor beras hingga jagung sepanjang 2018. Retrieved from https://finance.detik.com/berita-ekonomibisnis/d-4360541/heboh-ri-impor-berashingga-jagung-sepanjang-2018 